\title{
Effect of Fermented Poultry and Cow Manures on Performance and Productivity of Two Alfalfa (Medicago sativa L.) Cultivars Grown in arid Saline Environment
}

\section{Awad Abusuwar ${ }^{1 *}$ and Ali Elsafori ${ }^{2}$ \\ ${ }^{1}$ Professor, Department of Arid land agriculture, College of Meteorology, Environment and Arid land Agriculture, King Abdulaziz University, KSA}

${ }^{2}$ Associate Professor, Department of Arid land agriculture, College of Meteorology, Environment and Arid land Agriculture, King Abdulaziz University, KSA

*Corresponding Author: Awad Abusuwar, Professor, Department of Arid land agriculture, College of Meteorology, Environment and Arid land Agriculture, King Abdulaziz University, KSA.

Received: May 23, 2019; Published: June 18, 2019

DOI: 10.31080/ASAG.2019.03.0532

\section{Abstract}

A field experiment was carried out during two successive years (2018/19) in the Agricultural Research Station of King Abdulaziz University at Hada Al-Sham, about $40 \mathrm{~km}$ northeast of Mecca.

The objectives of the study were to evaluate growth and productivity of two alfalfa cultivars (local cultivar Hegazi and exotic cultivar Siriver) in a saline arid environment with the aid of using fermented poultry manure (PM) and cow manure (CM). The treatments included fermented Poultry manure at a rate of 4 tons ha ${ }^{-1}$ (PM), four tons ha ${ }^{-1}$ fermented cow manure (CM), a mixture of poultry and cow manures at a rate of two tons ha of each, in addition to a control check. These were tested on two cultivars of alfalfa. A split plot design was used where cultivars were randomly assigned to main plots and manure treatments to subplots. Growth parameters of plant height and leaf/stem ratio were measured, in addition to forage productivity in terms of fresh and dry yields in nine cuts during the course of the study.

Results indicated that the local cultivar Hegazi grew taller than the exotic cultivar Siriver but Siriver had more leaves than Hegazi.

For the manure treatments, significant differences for the manure treatments were recorded throughout the nine cuts. The ranking order for the manure treatments was $\mathrm{PMCM}>\mathrm{PM}>\mathrm{CM}>$ control. The increments in forage fresh yield were 105,71 , and $25 \% \mathrm{com}$ pared to the control treatment for PMCM, PM and CM, respectively. Corresponding increments in dry forage yields were 106, 70 and $22 \%$ compared to the control for PMCM, PM and CM, respectively.

It can be concluded that fermented manure is an effective tool to boost production in arid saline soils when adapted cultivars are used.

Keywords: Fermented Manure; Saline Arid Land; Alfalfa Cultivars; Forage Production

\section{Introduction}

Arid lands are characterized by fragile ecosystems, low land productivity, limited good quality irrigation water and non-sustainable farming systems. The Kingdom of Saudi Arabia entirely lies within arid land zone, with an annual rainfall ranging from 0 to $100 \mathrm{~mm} /$ annum. This limited rainfall is coupled with high evaporation rates, so the cultivable pockets in valleys of the western region, which mostly depends on saline irrigation, become more saline as a result of secondary salinization created. The saline and harsh climatic condition hinder the growth and productivity of crops through physiological stress, limitation of nutrient uptake and mitigation of beneficial microorganisms (Rhizobium bacteria and mycorrhizal fungi). as stated by Ventorino., et al. [1]. Therefore, addition of organic fertilizers in such soils to supply plants with essential elements and improve soil physical characteristics was a necessity.

Organic farming has become one of the fastest growing segments of agriculture throughout the world. In conventional agriculture system, use of chemicals has worried people about food quality, sustainability and other environmental consequences while organic agriculture assures high-quality food, sustainability 
and protect the environment [2,3]. Saudi Arabia has low soil organic matter. It is well known that enrichment of organic matter reduces salinity effects, increases moisture conservation, and as result stimulates crop growth and quality [4]. The use of organic fertilizers, particularly poultry and cow manures, are known to benefit soils under such adverse environment through improving soil physical and chemical properties, thereby enhancing crop productivity [5]. Several researchers pointed out that organic manure helps in conserving cropping systems through recycling of nutrients [6,7]. Moreover, Khan., et al. [8] reported that addition of organic manures with crop residues led to an increase in available phosphorus in soil. On the other hand, the use of inorganic fertilizers, particularly under saline condition, has not been helpful. It is often associated with reduced crop yield, cause soil acidity and nutrient imbalances [9].

Alfalfa is an important forage crop in Saudi Arabia that is grown on $23 \%$ of the total cropping area. In recent years, however, the Kingdom relies mainly on importation of alfalfa hay to bridge the feed gap, which amounts to $50 \%$ of required to feed animals in the Kingdom [10]. Generally, alfalfa has the ability to establish symbiosis with rhizobia (Rhizobium melilotti sp.), which induces root nodules where biological nitrogen fixation takes place, conferring alfalfa organic acids as a carbon and energy source. Nodulation is regulated by some external (soil and environmental) and internal (genetic) factors [11]. Previously no effective nodulation has been observed in Hada Al-sham (area where this research was conducted) that was exposed to severe environmental conditions such as drought stress, salinity, alkalinity, acidity, organic matter deficiency. This fact was supported by the results of Esfahani., et al. [12], who has reported that salinity, alkalinity and genetic factors confines nodulation thereby reducing its yield.

The idea for the present research was to use fermented poultry and cow manures, which is abundant in the Kingdom, in improving both chemical and physical properties to enhance crop productivity in such saline arid environment. Moreover, fermentation of manure will lead to illumination of weed seeds and harmful pathogens from manure due to high heat generation during fermentation process.

\section{Material and Methods}

The experiment was carried out for two years on alfalfa in their growing seasons, from Feb. 2017 - January. 2019, in the Agriculture Research Farm of King Abdulaziz University at Hada Al-Sham, Saudi Arabia. The site is located about $40 \mathrm{~km}$ northeast of Mecca. The site soil has a very poor productivity probably due to salinity problem. Details of soil chemical properties of the site before and after planting were presented in Table 1. Climatic conditions for average monthly temperature and rainfall were given in Figure 1. A randomized complete block design with split plot layout was used. The main plot treatments were two cultivars; Hegazi, which is a local commercially grown cultivar in Saudi Arabia and an introduced cultivar, Siriver from Australia. The subplot treatments were fermented poultry and cow manures applied separately and as a mixture plus a control. The cow and poultry manures were put in pits for four months to insure complete fermentation to kill weed seeds and pathogens before use in the experiment. Thereafter, it was incorporated into soil before planting. After completion of the fermentation process, the manures were analyzed for their chemical composition (Table 2). Treatment structure for the subplots was as follows: 4 tons ha- 1 of fermented Poultry Manure (PM), 4 tons ha- 1 of fermented Cow Manure (CM), 2 tons ha- 1 of PM +2 tons of fermented cow manure as a mixture (PMCM) ha-1, plus a control. Each subplot size was $3 \times 2 \mathrm{~m}$. The experimental site was ploughed with a ridger having ridge to- ridge $70 \mathrm{~cm}$ distance, then seeds were broadcasted on the first week of Feb. 2018 and the experiment continued up to Jan.2019. Surface irrigation with plastic pipes running along each furrow and perforated to allow free and uniform flow of water was installed. Irrigation was applied every 3 or 4 days according to weather condition. Underground water containing 3500 TDS (ppm) was the source of irrigation. The following growth and yield parameters were taken at each cut throughout the experimental period:

- Plant height: Ten random plants from each subplot were tak en for measuring plant height from soil surface to tip of plant.

- Leaf/stem ratio: The same ten plants used for measuring height were used for leaf/stem ratio determination. Leaves of the ten plants were stripped from their stems and oven dried at $85^{\circ} \mathrm{C}$ until a constant weight was reached, then weight of leaves was divided by weight of stems to get leaf/stem ratio.

- Forage fresh and dry yields: For fresh yield, the entire sub plot was harvested and fresh yield was taken immediately

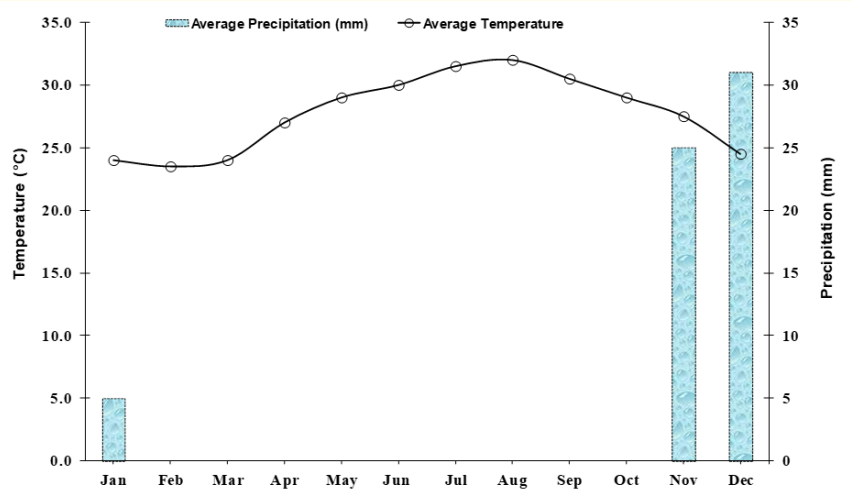

Figure 1: Ten years average temperature $(\mathrm{OC})$ and Precipitation (mm) of Hada-Al Sham, Jeddah-Saudi Arabia. 
Effect of Fermented Poultry and Cow Manures on Performance and Productivity of Two Alfalfa (Medicago sativa L.) Cultivars Grown in arid Saline Environment

\begin{tabular}{|l|c|c|c|c|c|c|c|c|c|}
\hline \multicolumn{1}{|c|}{ Chem. property } & $\mathbf{E c}$ & $\mathbf{p H}$ & $\mathbf{O M} \%$ & $\mathbf{N \%}$ & $\mathbf{P \%}$ & $\mathbf{C a} \%$ & $\mathbf{M g \%}$ & $\mathbf{K \%}$ & $\mathbf{N a \%}$ \\
\hline Before planting & 5.5 & 7.72 & 0.45 & 0.02 & 0.247 & 2.83 & 2.69 & 0.35 & 0.35 \\
\hline After planting: & & & & & & & & & \\
\hline Control & 3.5 & 7.86 & 0.48 & 0.02 & 0.041 & 2.04 & 2.34 & 0.24 & 0.27 \\
\hline PM & 3.7 & 7.91 & 0.50 & 0.00 & 0.247 & 2.35 & 2.44 & 0.25 & 0.24 \\
\hline CM & 5.3 & 7.86 & 0.49 & 0.01 & 0.124 & 2.32 & 2.57 & 0.26 & 0.25 \\
\hline PMCM & 3.6 & 7.90 & 0.71 & 0.07 & 0.082 & 2.59 & 2.66 & 0.34 & 0.31 \\
\hline
\end{tabular}

Table 1: Chemical properties of the site soil before and after planting.

${ }^{* *} \mathrm{PM}=4$ tons $\mathrm{ha}^{-1}$ of fermented poultry manure, $\mathrm{CM}=4$ tons ha ${ }^{-1}$ of fermented cow manure, $\mathrm{PMCM}=2$ tons ha ${ }^{-1}$ of fermented cow manure +2 tons $\mathrm{N}$ ha ${ }^{-1}$ of fermented poultry manure.

\begin{tabular}{|l|c|c|c|c|c|}
\hline & $\mathbf{N}\left(\mathbf{g k g}^{-1}\right)$ & $\mathbf{P}\left(\mathbf{g k g}^{-1}\right)$ & $\mathbf{K}\left(\mathbf{g k g}^{-1}\right)$ & $\mathbf{C}\left(\mathbf{g k g}^{-1}\right)$ & $\mathbf{C} / \mathbf{N}$ \\
\hline Poultry manure & 16.35 & 3.90 & 23.95 & 255 & 16.1 \\
\hline Cow manure & 7.58 & 1.02 & 12.80 & 87 & 13.1 \\
\hline
\end{tabular}

Table 2: Chemical analysis of chicken and Farmyard (cow) manures after fermentation.

using a spring balance. Data was taken in gms per subplot then transformed into tons ha ${ }^{1}$. For dry weight, a sample from each subplot was taken, weighed fresh and then put into an oven at $85^{\circ} \mathrm{C}$ until a constant weight was reached. Then dry weight was calculated from the formula: Dry weight per subplot = Sample dry weight $\times$ Subplot fresh

\section{Soil analysis}

Ten random soil samples from the experimental site were analyzed for the chemical properties of the soil using an auger to a depth of $30 \mathrm{~cm}$ before planting and a sample from each subplot at the end of experiment. Chemical properties of soil were presented in Table 1.

\section{Meteorological data}

Meteorological data of precipitation and temperature were taken as an average of the last ten years and presented in Figure 1.

The following growth and yield parameters were taken during the course of the study.

\section{Results}

\section{Soil Chemical Analysis before and after experimentation}

Results of soil analysis of the experimental site before and after experimentation is presented in Table 1. The Ec dropped after experimentation for all treatments except Cattle manure treatment (CM). On the other hand, soil pH slightly raised with treatment application. Organic matter showed an increase with the application of manure with highest value recorded for mixture of manure (PMCM) treatment. All elements studied ( $\mathrm{Ca}, \mathrm{Mg}, \mathrm{K}$ and $\mathrm{Na}$ ) dropped with application of treatments probably by higher uptake of plants to these elements. It should be recalled here that the irrigation water salinity was 3500 TDS (ppm).

\section{Chemical analysis of fermented manures}

Chemical analysis of the fermented organic manures indicated that poultry manure contained almost three folds nutrients compared to cow manure (Table 2).

Meteorological data of average precipitation and average temperature for the experimental site in ten years is presented in Figure 1 . Average temperature was around $25^{\circ} \mathrm{C}$ during rainy season (Nov. Dec. and January) and increased up to $34^{\circ} \mathrm{C}$ for the rest of the months. Average precipitation showed rainfall during Nov, Dec and January being the peak month for rainfall.

Effect of treatments on growth parameters:

Plant height (cm)

Plant height was measured nine times, at each cut, during the study period (Table 3). In the main plot treatments, no significant differences were reported for both cultivars although the Hegazi cultivar exceeded Siriver in seven out of nine cuts.

In the subplot treatments, significant differences were reported in plant height throughout the nine cuts. The shortest plants were recorded for the control treatment, whereas the tallest plants were recorded for the manure mixed treatment (PMCM). Followed by the poultry treatment (PM) and then the cattle manure treatment (CM).

\section{Leaf/stem ratio}

Results of leaf/stem ratio on dry matter basis were presented in Table 4. In the main plot treatments, significant differences were reported in three out of nine cuts (Cuts 3,5 and 8) when the cultivar Siriver outscored the cultivar Hegazi. In the six remaining cuts, though no significant differences were reported, yet the Siriver cultivar outscored Hegazi in leaf/stem ratio. 
Effect of Fermented Poultry and Cow Manures on Performance and Productivity of Two Alfalfa (Medicago sativa L.) Cultivars Grown in arid Saline Environment

\begin{tabular}{|l|c|c|c|c|c|c|c|c|c|}
\hline Treatments & $\mathbf{1}^{\text {st }}$ cut & $\mathbf{2}^{\text {nd }}$ cut & $\mathbf{3}^{\text {rd }}$ cut & $\mathbf{4}^{\text {th }}$ cut & $\mathbf{5}^{\text {th }}$ cut & $\mathbf{6}^{\text {th }}$ cut & $\mathbf{7}^{\text {th }}$ cut & $\mathbf{8}^{\text {th }}$ cut & $\mathbf{9}^{\text {th }}$ cut \\
\hline Main plots & $12 / 5 / 2018$ & $19 / 6$ & $19 / 7$ & $26 / 8$ & $27 / 9$ & $28 / 10$ & $29 / 11$ & $29 / 12$ & $28 / 1 / 2019$ \\
\hline H & $49.5 \mathrm{a}$ & $45.3 \mathrm{a}$ & $62.9 \mathrm{a}$ & $52.0 \mathrm{a}$ & $59.8 \mathrm{a}$ & $51.6 \mathrm{a}$ & $63.5 \mathrm{a}$ & $65.4 \mathrm{a}$ & $66.1 \mathrm{a}$ \\
\hline S & $48.0 \mathrm{a}$ & $43.3 \mathrm{a}$ & $62.6 \mathrm{a}$ & $53.8 \mathrm{a}$ & $58.6 \mathrm{a}$ & $51.3 \mathrm{a}$ & $62.8 \mathrm{a}$ & $65.3 \mathrm{a}$ & $69.1 \mathrm{a}$ \\
\hline LSD at0.05 & 4.1 & 4.6 & 3.2 & 4.3 & 2.3 & 2.4 & 3.3 & 3.5 & 3.0 \\
\hline Sub-plots & & & & & & & & & \\
\hline Control & $40.5 \mathrm{c}$ & $34.5 \mathrm{c}$ & $56.0 \mathrm{c}$ & $46.3 \mathrm{c}$ & $53.0 \mathrm{c}$ & $47.2 \mathrm{c}$ & $58.8 \mathrm{~b}$ & $58.7 \mathrm{c}$ & $61.8 \mathrm{~d}$ \\
\hline PM & $52.8 \mathrm{ab}$ & $47.5 \mathrm{ab}$ & $64.5 \mathrm{~b}$ & $54.7 \mathrm{~b}$ & $61.0 \mathrm{~b}$ & $53.0 \mathrm{ab}$ & $65.3 \mathrm{a}$ & $67.7 \mathrm{ab}$ & $69.8 \mathrm{~b}$ \\
\hline CM & $47.2 \mathrm{~b}$ & $41.5 \mathrm{~b}$ & $60.8 \mathrm{~b}$ & $52.3 \mathrm{~b}$ & $55.8 \mathrm{c}$ & $49.7 \mathrm{bc}$ & $60.3 \mathrm{~b}$ & $63.8 \mathrm{~b}$ & $65.8 \mathrm{c}$ \\
\hline PMCM & $54.5 \mathrm{a}$ & $53.7 \mathrm{a}$ & $69.7 \mathrm{a}$ & $58.3 \mathrm{a}$ & $66.8 \mathrm{a}$ & $56.0 \mathrm{a}$ & $68.0 \mathrm{a}$ & $71.2 \mathrm{a}$ & $72.8 \mathrm{a}$ \\
\hline LSD at 0.05 & 5.8 & 6.5 & 4.5 & 3.5 & 3.2 & 3.5 & 4.6 & 4.9 & 2.81 \\
\hline CV & 9.38 & 11.64 & 5.65 & 5.28 & 4.32 & 5.33 & 5.82 & 6.02 & 3.31 \\
\hline
\end{tabular}

Table 3: Effect of fermented poultry and cow manures on plant height $(\mathrm{cm})$ of two alfalfa cultivars grown under arid saline environment. Figures followed by same letter(s) in each column are not significantly different at 0.05 level using LSD Test.

H: Hegazi cultivar. S: Siriver cultivar

PM: poultry manure. CM: Cow manure. PMCM: mixture of poultry and cow manures

\begin{tabular}{|c|c|c|c|c|c|c|c|c|c|}
\hline Treatments & $1^{\text {st }}$ cut & $2^{\text {nd }}$ cut & $3^{\text {rd }}$ cut & $4^{\text {th }}$ cut & $5^{\text {th }}$ cut & $6^{\text {th }}$ cut & $7^{\text {th }}$ cut & $8^{\text {th }}$ cut & $9^{\text {th }}$ cut \\
\hline Main plots & $12 / 5 / 2018$ & $19 / 6$ & $19 / 7$ & $26 / 8$ & $27 / 9$ & $28 / 10$ & $29 / 11$ & $29 / 12$ & $28 / 1 / 19$ \\
\hline $\mathrm{H}$ & $3.46 \mathrm{a}$ & $0.97 a$ & $0.86 \mathrm{~b}$ & $1.61 \mathrm{a}$ & $1.13 b$ & $0.98 a$ & $1.17 \mathrm{a}$ & $1.08 \mathrm{~b}$ & $1.31 \mathrm{a}$ \\
\hline$S$ & $4.00 \mathrm{a}$ & $0.94 \mathrm{a}$ & $1.22 \mathrm{a}$ & $1.91 \mathrm{a}$ & $1.44 \mathrm{a}$ & $1.84 \mathrm{a}$ & $1.65 \mathrm{a}$ & $1.42 \mathrm{a}$ & $1.53 a$ \\
\hline LSD at 0.05 & 1.38 & 0.30 & 0.22 & 0.54 & 0.29 & 2.71 & 0.49 & 0.28 & 0.29 \\
\hline \multicolumn{10}{|l|}{ Sub-plots } \\
\hline Control & $2.56 \mathrm{~b}$ & $0.55 b$ & $0.61 c$ & $1.01 \mathrm{c}$ & $0.71 \mathrm{c}$ & $0.30 \mathrm{~b}$ & $0.91 b$ & $0.38 \mathrm{~d}$ & $0.77 \mathrm{c}$ \\
\hline PM & $4.25 \mathrm{ab}$ & $1.25 \mathrm{a}$ & $1.10 \mathrm{~b}$ & $1.83 \mathrm{~b}$ & $1.45 b$ & $0.88 \mathrm{~b}$ & $1.41 \mathrm{~b}$ & $1.36 \mathrm{~b}$ & $1.62 \mathrm{~b}$ \\
\hline $\mathrm{CM}$ & $3.46 \mathrm{~b}$ & $0.73 b$ & $0.73 c$ & $1.40 \mathrm{bc}$ & $0.80 \mathrm{c}$ & $0.51 \mathrm{~b}$ & $0.81 \mathrm{~b}$ & $0.93 c$ & $0.98 \mathrm{c}$ \\
\hline PMCM & $5.65 a$ & $1.30 \mathrm{a}$ & $1.73 \mathrm{a}$ & $2.81 \mathrm{a}$ & $2.18 \mathrm{a}$ & $1.95 \mathrm{a}$ & $2.51 \mathrm{a}$ & $2.33 \mathrm{a}$ & $2.33 \mathrm{a}$ \\
\hline LSD at 0.05 & 1.90 & 0.43 & 0.32 & 0.76 & 0.41 & 0.84 & 0.69 & 0.40 & 0.42 \\
\hline $\mathrm{CV}$ & 38.06 & 35.72 & 24.35 & 34.55 & 25.48 & 26.45 & 38.96 & 25.44 & 23.51 \\
\hline \multicolumn{10}{|l|}{ Interaction: } \\
\hline $\mathrm{HC}$ & & & $0.53 \mathrm{~d}$ & & $0.90 \mathrm{de}$ & & & $0.33 \mathrm{e}$ & \\
\hline HPM & & & $1.03 \mathrm{bc}$ & & $1.56 \mathrm{bc}$ & & & $1.00 \mathrm{~cd}$ & \\
\hline $\mathrm{HCM}$ & & & $0.66 \mathrm{~cd}$ & & $0.93 \mathrm{de}$ & & & $0.80 \mathrm{cde}$ & \\
\hline НРМСM & & & $1.23 \mathrm{~b}$ & & $2.36 \mathrm{a}$ & & & $2.20 \mathrm{ab}$ & \\
\hline S control & & & $0.70 \mathrm{~cd}$ & & $0.53 \mathrm{e}$ & & & $0.43 \mathrm{de}$ & \\
\hline SPM & & & $1.16 \mathrm{~b}$ & & $1.33 \mathrm{~cd}$ & & & $1.73 b$ & \\
\hline S CM & & & $0.80 \mathrm{bcd}$ & & $0.66 \mathrm{e}$ & & & $1.06 \mathrm{c}$ & \\
\hline S PMCM & & & $2.23 \mathrm{a}$ & & $2.00 \mathrm{ab}$ & & & $2.46 \mathrm{a}$ & \\
\hline LSD at 0.05 & & & 0.45 & & 0.58 & & & 0.56 & \\
\hline $\mathrm{CV}$ & & & 24.35 & & 25.48 & & & 25.44 & \\
\hline
\end{tabular}

Table 4: Effect of fermented poultry and cow manures on leaf/stem ratio of two alfalfa cultivars grown under arid saline environment. Figures followed by same letter(s) in each column are not significantly different at 0.05 level using LSD Test.

H: Hegazi cultivar. S: Siriver cultivar

PM: poultry manure. CM: Cow manure. PMCM: mixture of poultry and cow manures. 
Effect of Fermented Poultry and Cow Manures on Performance and Productivity of Two Alfalfa (Medicago sativa L.) Cultivars Grown in arid Saline Environment

For the subplot treatments, significant differences were reported for manure treatments. The mixed manure treatment (PMCM) outscored other treatments throughout the nine cuts with the minimum leaf/stem ratio reported for the control treatment.

Significant interactions between cultivars and the manure treatments were observed in cuts 3, 5 and 8. The Siriver cultivar with manure mixture exceeded the Hegazi cultivar with manure mixture in cuts number 3 and 8, whereas the Hegazi exceeded the Siriver in cut 5. Minimum leaf/stem ratio was always recorded in the control treatment.

\section{Forage production}

Fresh forage yield (tons ha-1)

Effect of treatments on fresh yield production was presented in Table 5. In the main plot treatments significant differences between the two cultivars were recorded in cuts 2 and 8 when the Hegazi cultivar out yielded the Siriver cultivar. The Siriver cultivar out yielded the Hegazi only in the first cut and the difference was not significant.

\begin{tabular}{|c|c|c|c|c|c|c|c|c|c|}
\hline Treatments & $1^{\text {st }}$ cut & $2^{\text {nd }}$ cut & $3^{\text {rd }}$ cut & $4^{\text {th }}$ cut & $5^{\text {th }}$ cut & $6^{\text {th }}$ cut & $7^{\text {th }}$ & $8^{\text {th }}$ cut & $9^{\text {th }}$ cut \\
\hline Main plots & $12 / 5 / 2018$ & $19 / 6$ & $19 / 7$ & $26 / 8$ & $27 / 9$ & $28 / 10$ & cut29/11 & $29 / 12$ & $28 / 1 / 19$ \\
\hline $\mathrm{H}$ & $12.95 a$ & $12.44 \mathrm{a}$ & $16.25 a$ & $14.78 \mathrm{a}$ & $19.07 \mathrm{a}$ & $16.28 a$ & $22.12 \mathrm{a}$ & $21.51 \mathrm{a}$ & $22.68 \mathrm{a}$ \\
\hline$S$ & $13.38 \mathrm{a}$ & $10.81 \mathrm{~b}$ & $16.22 \mathrm{a}$ & $12.99 a$ & $17.74 a$ & $17.03 \mathrm{a}$ & $19.60 \mathrm{~b}$ & $19.00 \mathrm{a}$ & $22.38 \mathrm{a}$ \\
\hline LSD at 0.05 & 2.33 & 1.21 & 2.13 & 2.58 & 3.50 & 2.16 & 2.45 & 2.52 & 2.78 \\
\hline \multicolumn{10}{|l|}{ Sub-plots } \\
\hline Control & $8.03 c$ & $7.19 \mathrm{~d}$ & $9.38 \mathrm{~d}$ & $9.69 \mathrm{~b}$ & $10.28 \mathrm{c}$ & $11.53 \mathrm{~b}$ & $14.45 \mathrm{c}$ & $14.96 \mathrm{c}$ & $16.65 \mathrm{c}$ \\
\hline PM & $15.16 \mathrm{~b}$ & $13.66 \mathrm{~b}$ & $18.79 \mathrm{~b}$ & $16.52 \mathrm{a}$ & $22.28 a$ & $19.00 \mathrm{a}$ & $23.48 \mathrm{~b}$ & $22.22 \mathrm{~b}$ & $23.91 \mathrm{~b}$ \\
\hline $\mathrm{CM}$ & $10.80 \mathrm{c}$ & $9.70 \mathrm{c}$ & $13.53 \mathrm{c}$ & $10.45 b$ & $15.49 \mathrm{~b}$ & $14.03 \mathrm{~b}$ & $17.33 \mathrm{c}$ & $17.16 \mathrm{c}$ & $19.52 \mathrm{c}$ \\
\hline PMCM & $18.67 \mathrm{a}$ & $15.95 a$ & $23.27 \mathrm{a}$ & $18.87 \mathrm{a}$ & $25.56 a$ & $22.05 a$ & $28.19 a$ & $26.68 \mathrm{a}$ & $30.03 a$ \\
\hline LSD at 0.05 & 3.28 & 1.71 & 3.01 & 3.65 & 4.95 & 3.06 & 3.47 & 3.56 & 3.93 \\
\hline $\mathrm{CV}$ & 19.82 & 11.70 & 14.73 & 20.90 & 21.38 & 14.61 & 13.21 & 13.97 & 13.87 \\
\hline \multicolumn{10}{|l|}{ Interaction: } \\
\hline $\mathrm{HC}$ & & $7.50 \mathrm{e}$ & & & & & $14.50 \mathrm{~d}$ & & \\
\hline HPM & & $14.61 \mathrm{~b}$ & & & & & $25.94 a$ & & \\
\hline $\mathrm{HCM}$ & & 8.86de & & & & & $17.46 \mathrm{~cd}$ & & \\
\hline НРМСM & & $18.78 \mathrm{a}$ & & & & & $30.59 a$ & & \\
\hline S control & & $6.88 \mathrm{e}$ & & & & & $14.41 \mathrm{~d}$ & & \\
\hline SPM & & $13.71 \mathrm{bc}$ & & & & & $21.02 \mathrm{bc}$ & & \\
\hline $\mathrm{S}$ CM & & $10.54 \mathrm{~cd}$ & & & & & $17.19 \mathrm{~cd}$ & & \\
\hline S PMCM & & $13.12 \mathrm{~b}$ & & & & & $25.77 \mathrm{ab}$ & & \\
\hline LSD at 0.05 & & 2.42 & & & & & 4.90 & & \\
\hline $\mathrm{CV}$ & & 11.70 & & & & & 13.21 & & \\
\hline
\end{tabular}

Table 5: Effect of fermented poultry and cow manures on fresh yield (tons/ha) of two alfalfa cultivars grown under arid saline environment.

Figures followed by same letter(s) in each column are not significantly different at 0.05 level using LSD Test.

H: Hegazi cultivar. S: Siriver cultivar

PM: poultry manure. CM: Cow manure. PMCM: mixture of poultry and cow manures.

For the subplot treatments, significant differences were recorded between manure treatments in all cuts throughout the experimental period. The highest fresh forage production was always recorded for mixed manure treatment (PMCM), whereas the lowest forage production was always recorded for the control treatment in all cuts. The ranking order for manure treatments with respect to fresh yield was as follows: $\mathrm{PMCM}>\mathrm{PM}>\mathrm{CM}>$ control. The percent increments in fresh yield resulting from manure application were
105, 71, and 25\%, compared to the control treatment, for PMCM, $\mathrm{PM}$ and $\mathrm{CM}$, respectively.

Interaction between cultivars and manure treatments were observed in cuts 2 and 7 only. In both cuts the Hegazi cultivar out yielded the Siriver when treated with manure mixture. The lowest fresh forage yield was always recorded for the control treatment regardless of the cultivar used. 
Effect of Fermented Poultry and Cow Manures on Performance and Productivity of Two Alfalfa (Medicago sativa L.) Cultivars Grown in arid Saline Environment

Forage dry matter production (tons ha' ${ }^{-1}$ )

Dry matter production as affected by treatments was presented in Table 6. The Hegazi cultivar produced more dry forage than the Siriver cultivar throughout the 9 cuts, but significant differences were reported in the $2^{\text {nd }}$ and $8^{\text {th }}$ cuts only. In the subplot treatments, significant differences were reported for the manure treatments in all nine cuts. The mixture of poultry and cow ma- nures (PMCM) resulted in the highest dry forage throughout the experimental period, whereas the lowest dry matter was recorded for the control treatment. The ranking order for the manure treatments in dry matter production, similar to fresh yield production, was as follows: $\mathrm{PMCM}>\mathrm{PM}>\mathrm{CM}>$ control. The percent increments in dry matter production as a result of manure application were 106, 70 and 22\%, compared to the control, for PMCM, PM and CM, respectively.

\begin{tabular}{|c|c|c|c|c|c|c|c|c|c|}
\hline Treatments & $1^{\text {st }}$ cut & $2^{\text {nd }}$ cut & $3^{\text {rd }}$ cut & $4^{\text {th }}$ cut & $5^{\text {th }}$ cut & $6^{\text {th }}$ cut & $7^{\text {th }}$ cut & $8^{\text {th }}$ cut & $9^{\text {th }}$ cut \\
\hline Main plots & $12 / 5 / 2018$ & $19 / 6$ & $19 / 7$ & $26 / 8$ & $27 / 9$ & $28 / 10$ & $29 / 11$ & $29 / 12$ & $28 / 1 / 2019$ \\
\hline $\mathrm{H}$ & $3.74 \mathrm{a}$ & $3.55 a$ & $4.33 a$ & $4.87 \mathrm{a}$ & $4.76 a$ & $9.96 \mathrm{a}$ & $15.69 a$ & $15.73 a$ & $9.98 \mathrm{a}$ \\
\hline S & $3.59 a$ & $3.08 \mathrm{~b}$ & $4.28 \mathrm{a}$ & $4.74 \mathrm{a}$ & $4.57 \mathrm{a}$ & $9.24 a$ & $14.39 \mathrm{a}$ & $13.22 \mathrm{~b}$ & $9.73 a$ \\
\hline LSD at0.05 & 0.16 & 0.39 & 0.63 & 0.80 & 0.77 & 1.97 & 3.21 & 2.36 & 0.44 \\
\hline \multicolumn{10}{|l|}{ Sub-plots } \\
\hline Control & $2.18 \mathrm{~d}$ & $2.15 \mathrm{~d}$ & $2.71 \mathrm{c}$ & $2.81 \mathrm{~b}$ & $2.55 \mathrm{c}$ & $6.24 \mathrm{c}$ & $9.53 \mathrm{~b}$ & $9.76 \mathrm{~b}$ & $8.70 \mathrm{c}$ \\
\hline PM & $4.03 \mathrm{~b}$ & $3.85 \mathrm{ab}$ & $5.04 \mathrm{a}$ & $5.92 \mathrm{a}$ & $4.93 \mathrm{~b}$ & $10.09 \mathrm{~b}$ & $17.91 \mathrm{a}$ & $17.27 \mathrm{a}$ & $10.08 \mathrm{~b}$ \\
\hline $\mathrm{CM}$ & $3.16 \mathrm{c}$ & $2.72 \mathrm{c}$ & $3.91 \mathrm{~b}$ & $3.50 \mathrm{~b}$ & $3.97 \mathrm{~b}$ & $8.66 b c$ & $10.98 \mathrm{~b}$ & $10.56 \mathrm{~b}$ & $9.60 \mathrm{~b}$ \\
\hline PMCM & $5.28 a$ & $4.49 \mathrm{a}$ & $5.59 a$ & $7.00 \mathrm{a}$ & $7.21 \mathrm{a}$ & $13.42 \mathrm{a}$ & $21.75 a$ & $20.31 \mathrm{a}$ & $11.02 \mathrm{a}$ \\
\hline LSD at 0.05 & 0.74 & 0.39 & 0.89 & 1.13 & 1.09 & 2.79 & 4.54 & 3.34 & 0.62 \\
\hline $\mathrm{CV}$ & 15.99 & 13.22 & 16.42 & 18.81 & 18.64 & 23.11 & 23.99 & 18.35 & 5.04 \\
\hline \multicolumn{10}{|l|}{ Interaction: } \\
\hline $\mathrm{HC}$ & & $2.23 \mathrm{ef}$ & & & & & & $10.35 c$ & \\
\hline HPM & & $4.31 \mathrm{ab}$ & & & & & & $18.99 \mathrm{ab}$ & \\
\hline $\mathrm{HCM}$ & & $2.59 \mathrm{ef}$ & & & & & & $10.52 \mathrm{c}$ & \\
\hline НРМСM & & $5.09 a$ & & & & & & $23.05 a$ & \\
\hline S control & & $2.08 \mathrm{f}$ & & & & & & $9.17 \mathrm{c}$ & \\
\hline SPM & & $3.40 \mathrm{~cd}$ & & & & & & $15.55 b$ & \\
\hline S CM & & $2.95 \mathrm{de}$ & & & & & & $10.60 \mathrm{c}$ & \\
\hline S PMCM & & $3.89 \mathrm{bc}$ & & & & & & $17.55 \mathrm{~b}$ & \\
\hline LSD at 0.05 & & 0.78 & & & & & & 4.73 & \\
\hline $\mathrm{CV}$ & & 13.22 & & & & & & 18.35 & \\
\hline
\end{tabular}

Table 6: Effect of fermented poultry and cow manures on dry matter production (tons/ha) of two alfalfa cultivars grown under arid saline environment.

Figures followed by same letter(s) in each column are not significantly different at 0.05 level using LSD Test.

H: Hegazi cultivar. S: Siriver cultivar

PM: poultry manure. CM: Cow manure. PMCM: mixture of poultry and cow manures.

Interaction between cultivars and manure treatments was significant in cuts 2 and 8 only. The highest dry yield was recorded for the Hegazi cultivar treated with mixture of poultry and cow manure (HPMCM) compared to Siriver with poultry and cow manure (SiPMCM). The minimum dry matter production was recorded for the Siriver cultivar in the control treatment for both cuts.

It is noticeable that growth parameters and productivity increased during the last three cuts (November, December and January) in all treatments as this period coincided with the rainy months (Figure 1).

\section{Discussion}

Effect of treatments on growth attributes

Growth attributes studied for the two alfalfa cultivars included plant height and leaf/stem ratio. For both characters, the fermented mixed poultry and cow manures resulted in significantly taller plants and higher leaf/stem ratio compared to the control treatment. This was expected as the addition of organic manure to saline soils improves soil physical properties like porosity, which enhances aeration and water infiltration. Moreover, poultry ma- 
nure contributes to soil fertility and as indicated in Table 2, poultry manure contained three folds nutrient elements compared to cow manure. These results are confirmed by Ayoola and Adeniyan [13] in Nigeria and Abusuwar and El Zilal [5] in Sudan in their studies of the influence of organic manures on productivity.

With respect to cultivars, the Hegazi cultivar was taller than the Siriver but the Siriver cultivar produced significantly more leaves than Hegazi. This is an important character regarding feed quality for the Siriver cultivar. Many researchers (Humphries and Hughes, 2006; Kalu and Fick, 1983; Sanderson and Wedin, 1988 and Marvin., et al. 2000) reported alfalfa cultivars differ in their quality support this finding.

\section{Effect of treatments on forage productivity}

Forage productivity, in terms of fresh and dry matter, was significantly affected by manure treatments. This was especially true for poultry manure applied alone or in combination with cow manure. The ranking order for the manure treatments in forage fresh and dry yields was $\mathrm{PMCM}>\mathrm{PM}>\mathrm{CM}>$ control. As indicated for growth attributes (height and leaf/stem ratio) which were positively affected by manure application, it is expected to be reflected in forage productivity. It is worth mentioning that chemical analysis of the experimental site had low organic matter, nitrogen, phosphorus, potassium and high content of sodium and this was reflected in lower productivity of the control treatment. Zirbin and Aragues [4] stated that organic manure reduces salinity effect, increases moisture conservation and stimulates crop growth and quality. Moreover, Ze Ping., et al. [7] pointed out that organic manure help in conserving cropping system through recycling of nutrients.

With respect to cultivars, the Hegazi produced more fresh and dry forage compare to Siriver. This could be attributed to the fact that the local cultivar Hegazi is was more adapted to the local conditions than the exotic Siriver.

It is noticeable that growth parameters and productivity increased during the last three cuts (November, December and January) in all treatments as this period coincided with the rainy months (Figure 1). This might be related to the effect of rain in washing salt crusts that appear on soil surface and the drop in temperature, which reduces evaporation that mitigates formation of salt crust.

\section{Conclusion}

It can be concluded from the results of this study that fermented poultry and cow manures, whether applied alone or mixed together, can be effective in enhancing growth and productivity of crops under saline arid environment.

\section{Bibliography}

1. Ventorino V., et al. "Response to salinity stress of Rhizobium leguminosarum by. Viciae strains in the presence of different legume host plants". Annals of Microbiology 62.2 (2012): 811823.

2. Treadwell, D., et al. "What is organic farming? Extension" (2013).

3. Sabrina DT., et al. "Effect of mixed organic-inorganic fertilizer on growth and phosphorus uptake of Setaria grass (Setaria splendid)". Australian Journal of Crop Science 7.1 (2013): 7583.

4. Zirbi W., et al. "Mulching effects on moisture, temperature, structure and salinity of agricultural soils". ITEA 107 (2011): 148-162.

5. Abusuwar AO and El Zilal H. "Effect of chicken manure on yield, quality and HCN concentration of two forage sorghum (Sorghum bicolor L. Moench) cultivars". Agriculture and Biology Journal of North America (ABJNA) 1 (2010): 27-31.

6. Dominguez A., et al. "Organic farming fosters agroecosystem functioning in Argentinean temperate soils: Evidence from litter decomposition and soil fauna". Applied Soil Ecology 83 (2014): 170-176.

7. Ze Ping., et al. "Effects of Long- Term Winter Planted Green Manure on Distribution and Storage of Organic Carbon and Nitrogen in Water-Stable Aggregates of Reddish Paddy Soil Under a Double-Rice Cropping System". International Journal of Agriculture 13 (2014): 1772- 1781.

8. Khan HZ., et al. "Effect of rate and source of organic material on the production potential of spring maize (Zea mays L.)". Pakistan Journal of Agricultural Sciences 45 (2008): 40-43.

9. Abusuwar AO and A Bakhshawain. "Effect of different chemical fertilizers on seed yield and seed yield components of alfalfa grown under stress environment of western Saudi Arabia”. International Journal of Disaster Risk Science 3.1 (2011): 114-116.

10. Ministry of water and Agriculture. KSA Agriculture statistic yearbook (2018)

11. Peix A., et al. "Bacterial Associations with Legumes". Critical Reviews in Plant Sciences 34 (2015): 17-42. 
Effect of Fermented Poultry and Cow Manures on Performance and Productivity of Two Alfalfa (Medicago sativa L.) Cultivars Grown in arid Saline Environment

12. Esfahani MN., et al. "Mechanisms of physiological adjustment of N2 fixation in Cicer arietinum L. (chickpea) during early stages of water deficit: single or multi-factor controls". Plant Journal 79.4 (2014): 964-980.

13. Ayoola OT and Adeniyan ON. "Influence of poultry manure and NPK on yield and yield components of crops under different cropping systems in southwest Nigeria". African Journal of Biotechnology 5.15 (2008): 1386-1392.

\section{Volume 3 Issue 7 July 2019}

(C) All rights are reserved by Awad Abusuwar and Ali

Elsafori. 